УДК 159.964.21:316.614.5

Чмуневич Наталія

здобувач вищого освітнього ступеня «Магістр», спеціальності «Психологія»

ORCID iD: 0000-0002-7699-1475

Павелків Віталій

д. психол. н.,професор, декан психолого-природничого факультету Рівненського державного гуманітарного університету ORCID iD:0000-0003-3321-9060 DOI https://doi.org/10.35619/prap_rv.vi13.142

\title{
ОСОБЛИВОСТІ РОЗУМІННЯ ФЕНОМЕНУ СВОБОДИ В ПІДЛТКОВОМУ ТА ЮНАЦЬКОМУ ВІЦІ
}

\begin{abstract}
Анотація. Розглянуто психологічний аспект феномену свободи. Здійснено теоретичний аналіз психологічних джерел до розуміння сутності явища психологічної свободи в зарубіжних та вітчизняних джерелах. Запропоновано теоретичну модель психологічної свободи особистості. Емпірично досліджено суб'єктивні уявлення феномену свободи молоді. Поняття свободи істотно змінюється з віком, залежить від рівня розвитку, мислення, особистості, самосвідомості, моральності, а також інтегрованості особистості в групі,соиіумі, культурі. Воно несе в собі відбиток уявлень про свободу, прийнятих на даному рівні розвитку суспільства, визначається орієнтаціями на свободу вікових груп. У визначенні свободи в інтегрованій формі поєднуються соціальне значення изієї категорії та індивідуальне розуміння - результат особистого досвіду зіткнення 3 перешкодами, подолання залежностей.

Аналізуючи уявлення про свободу, ставлення до неї і ї̈ досягнення, то можна сказати, щзоче залежить від багатьох причин, в тому числі від вікових та індивідуальних особливостей, особистісних якостей людини, рівня розвитку духовного потенціалу, свідомості і рефлексії, системи виховання $і$ навчання, норм, прав $i$ законів, прийнятих в суспільстві.
\end{abstract}

Ключові слова: незалежність; воля; психологічна свобода; самодетермінація; самоефективність; самосвідомість; свобода; суб'єктивність; феномен.

Постановка проблеми: Проблема свободи особистості на даний час $є$ однією 3 найбільш актуальних при вирішенні питань соціального самовизначення сучасної молоді в складних соціально-економічних умовах. Відповідно до поглядів Леонтьєва, людина здатна реалізувати свободу як психологічну реальність тільки в суспільстві собі подібних (2003, с. 124). У зв'язку з цим особливого значення феномен свободи особистості набуває в рамках підліткового періоду, тобто тієї соціальної спільності, коли найбільш зримо проявляються соціально-політичні та економічні зміни, що відбуваються в сучасному суспільстві.

Актуальність проблеми визначається і реальними протиріччями, що виникають в житті кожного підлітка. 3 одного боку, для повноцінного існування підліток потребує постійного опору в прагненнях до задоволення власних потреб, оскільки такий супротив забезпечує феномен актуального самопочуття і створює можливості розвитку (Бєлова, 2008, c. 1-3). 3 іншого боку, подолання опору задоволення тієї або іншої потреби завжди $\epsilon$ напруженимі при відсутності відповідного емоційно-вольової ресурсу призводить до деструктивних ефектів: конфліктів, стресу, агресії, девіацій і т.п. Крім того, аналіз причин поведінкових відхилень у підлітковому віці в руслі особистісного підходу піднімає проблему вивчення форм і механізмів реалізації свободи. Свобода для підлітка - це мрія (Фромм, 2016, c. 111). 
Не можна не згадати і про основний віковий діапазоном, в якому розгортаються численні зміни в осмисленні власного життєвого світу, розвиткові суб'єктної активності та професійного самовизначення, є юнацький вік, коли особливо актуалізуються потреби особистісного розвитку в їх різноманітних просторово-часових та соціально-структурних модифікаціях (Корчікова, 2013, с.47). Конкретизуючи зміст свободи особистості в юнацькому віці, важливо виокремити таку унікальну їі якість як психологічний простір, який розуміють як суб'єктивно значущий фрагмент буття, що визначає актуальну діяльність і стратегію життя людини та включає комплекс фізичних, соціальних і психологічних явищ, 3 якими людина себе ототожнює, а, отже, оберігає усіма доступними їй фізичними та психологічними засобами (Кузьмина, 2007, с. 45).

Аналіз останніх досліджень 3 проблеми. Поняття свободи довгий час було предметом вивчення філософії. Зараз актуальності набуває вивчення психологічного виміру свободи у зв’язку з тенденціями гуманізації суспільства, поширенням гуманістичної парадигми, становленням посткласичної наукової картини світу. Засадами дослідження слугували психологічні концепції свободи: свобода як усвідомлення і самосвідомість (Фромм, Мей, Мадді); самодетермінація і автономія (Харре, Річлак, Тейджсон, Десі і. Райан); складова самоактуалізації особистості ( Маслоу, Роджерс), самоефективність (А. Бандура), вільний вибір (Фромм,. Істербрук, Найссер), самодистанціювання тасамотрансцеденція (Франкл); форма активності ( Калітієвська, Леонтьєв); причинність (А. Петровський); проблема свободи через саморозвиток та самотворчість суб'єктним способом буття (Костюк, Рубінштейн, Максименко, Татенко, Абульханова, Леонтьєв та ін.). Поняття свободи особистості все частіше розуміється не як формуюча зовнішнім впливом, а як здатна до саморозвитку, самовизначення й самотворчості (Абульханова, Анциферова, Балл, Леонтьєв, Максименко, Петровський, Рубінштейн, Кузьміна, Татенко, Чудновський). Екзистенційний підхід та гуманістична психологія розглядають свободу як важливу умову функціонування особистості, складову іiі психічного здоров'я. У сучасній вітчизняній психології проблема свободи пов'язується з саморозвитком, самотворчістю, суб'єктним способом буття (Костюк, Рубінштейн, Максименко, Татенко, Абульханова, Леонтьєв, та ін.).

Мета статті. Метою статті $\epsilon$ теоретичне вивчення та емпіричне дослідження феномену психологічної свободи серед підлітків та юнаків.

Виклад основного матеріалу дослідження. Результати, отримані під час опитування випробовуваних за методикою «Я і світ», дозволяють описати деякі гендерні особливості феномена внутрішньої свободи. Так, в обох гендерних групах найбільш високими показниками серед усіх досліджуваних компонентів феномена внутрішньої свободи представлена «Позитивна життєва позиція»; іiі вираженість вище у дівчат, ніж у хлопців. Другу за вираженістю позицію займають показники сформованості переконань щодо здатності людини впливати на свою долю і протистояти зовнішнім обставинам (шкала «Детермінація і Самодетермінація»); середні показники цієї шкали не мають відмінностей в залежності від статі досліджуваних. Найменш представленої в загальній структурі досвіду внутрішньої свободи у хлопців є екзистенційне світосприйняття, показники якого значно нижче, ніж в дівчачій групі. У дівчат найменшими показниками представлені компоненти особистісного досвіду, пов'язані зі здатністю диференціювати «Я - не-Я».

Цікаві дані були отримані нами при аналізі вікової динаміки всіх показників опитувальника «Я і Світ» 3 урахуванням гендерного фактора. У жіночій вибірці відзначена деяка динаміка зростання показників позитивної життєвої позиції від підліткового до більш старшого віку, а в чоловічій групі відзначається їх істотне і послідовне зниження від підліткового періоду до юності (вікові відмінності статистично значущі тільки в чоловічій вибірці - на рівні $\mathrm{p}<0,05)$. Це говорить про те, що хлопці, які відносяться сьогодні до юнацького віку, мають менш позитивне сприйняття світу і себе в порівнянні з меншими віковими групами. Аналіз показників другої шкали - «Межа Я - не-Я» - показує, що в чоловічій вибірці відзначається їх зниження від юнацького періоду до підліткового, а потім невелике зростання до юнацького. Це означає, що юнаки в цілому краще диференціюють явища і процеси, які стосуються своєї і чужої компетенції і відповідальності, ніж підлітки. 
Дівчата, навпаки, у юнацькому віці дещо краще усвідомлюють диференціацію «Я - не-Я» в порівнянні з підлітками.

Вікова динаміка показників третьої шкали - «Детермінуючий вплив у відносинах» - в чоловічій групі накреслено більш різко, ніж в жіночій. У хлопців здатність проявляти волю до здійснення своїх прагнень, протистояти зовнішнім впливам найбільш яскраво виражена в підлітковий період; старша група хлопців мають більш низькі показники за цією шкалою, що свідчить про їх схильність більше приймати і підкорятися деяким подіям життя, обставинам, примхам долі, ніж будувати життя за власним задумом (відмінності встановлені на рівні p <0,05). У жіночій вибірці показники установок на власний вибір на противагу підпорядкування обставинам трохи вище в середній дорослості, а у дівчат юнацького віку помітно нижче, що так само, як і у чоловіків, виражається в більшій тенденції підкорятися зовнішнім впливам. Крім того, порівняння середніх показників третьої шкали в двох гендерних групах показує, що у віці від 18 до 23 років хлопці проявляють більшу в порівнянні з дівчатами, здатність до протистояння обставинам..

Наші результати показують також, що кожна вікова група випробовуваних має в цілому більш розвинені екзистенційні погляди, ніж попередня (вікові відмінності статистично значущі на рівні $\mathrm{p}<0,05)$. У двох вікових групах дівчата мають більш високі показники екзистенціальних поглядів в порівнянні з хлопцями. Ці дані говорять про те, що екзистенціальне світогляд $є$ значною мірою функцією віку. Порівняльний аналіз величини сумарного показника за опитувальником «Я і Світ» в залежності від вікового та гендерного факторів показує, що рівень переживання внутрішньої свободи в чоловічий вибірці виявляє велику залежність від віку, ніж в жіночій. Досвід внутрішньої свободи у хлопців в юнацькому періоді виражений значно менше, ніж в підлітковому віці. У той же час дівчата в юнацькому періоді переживають більшу внутрішню свободу, ніж в підлітковому віці.

Представники більш молодий вікової групи (від 12 до 16 років) показали більш низький рівень внутрішньої свободи. Період юності в наших соціокультурних умовах $є$ для особистості віком тривалого напруженого пошуку себе, придбання першого складного життєвого досвіду, що супроводжується втратою деяких ілюзій; це також період пошуку свого місця в соціумі і пов'язаних з ним тривог про можливу професійну незатребуваність i матеріальну невлаштованість. В силу цих факторів переживання досвіду внутрішньої свободи, яке передбачає віру в себе і свої сили, а також здатність утримувати кордон свого Я, не зливаючись з іншими, ймовірно, утруднене в порівнянні з підлітковим періодом, коли життя в основних своїх рисах вже ще не склалася, немає певного життєвого досвіду, не подолані перші серйозні труднощі життя.

В результаті опрацювання емпіричних даних за методикою Нартової-Бочавер «Суверенність психологічного простору» нами було визначено три основні групи респондентів з різними показниками суверенності психологічного простору: перша група високий показник суверенності психологічного простору $-34,25 \%$; друга група середній показник - 42,55 \%; третя група низький показник - 23,2 \%. Фіксація показників суверенності психологічного простору у загальній вибірці досліджуваних дає змогу стверджувати, що високий рівень вираження суверенності психологічного простору $\epsilon$ ознакою у 34\% досліджуваних студентів, а це означає, що ці студенти окреслили свій життєвий простір як найбільш значущу (близьку, улюблену, цікаву) для них частину життєвого світу, яка суб'єктивно визначає найважливішу сторону їх життєдіяльності. Така позиція високого рівня визначення суверенності власного психологічного простору найчастіше відображається у характеристиках особистості, пов'язаних з ії автономністю, самостійністю та стійкістю. Середній рівень вираження суверенності $є$ ознакою невизначеної позиції щодо визначення суверенності студентами свого психологічного простору, що часто пов'язано із соціальними факторами особистісної реалізації молодої людини, які перешкоджають або ж навіть руйнують потенціал формування цілісного, повноцінного особистісного простору. Низький рівень вираження суверенності психологічного простору досліджуваних засвідчує прояв у них ознак депривованості, яка проявляється в переживанні 
відчуження i фрагментарності власного життя, що характеризується суттєвими ускладненнями в пошуці об'єкту ідентифікації.

Аналіз середньогрупового розподілу показників за шкалами опитувальника показав, що в групі студентів із високим рівнем суверенності психологічного простору за усіма шкалами методики простежується виражений (високий) рівень, що є закономірним явищем супроводу вираженого загального почуття автономності, незалежності, самостійності власної особистості, які досягають засобом регуляції особистісних меж, передусім їх встановленням, що робить простір відкритим. Саме така реальна контрольованість життєвого середовища $\epsilon$ ознакою соціально-психологічної адаптації та психічного благополуччя людини, на відміну від реальних ознак встановлення захисних меж особистісного простору, як-от в групі студентів із низьким рівнем суверенності психологічного простору.

Результати дослідження дозволяють констатувати наявність зв'язку між переживанням порушення психологічного простору, обираними суб'єктом стратегіями психологічного подолання та наявністю вираженого внутрішньоособистісного конфлікту. Для молодих людей із зниженим рівнем суверенністю психологічного простору домінуючою стратегією копінг-поведінки $є$ втеча, їм притаманний внутрішньоособистісний конфлікт за суверенністю власного тіла й соціальних зв'язків; суб'єктам із здоровими межами притаманний пошук соціальної підтримки та планування як стратегії копінгу. Відсутні відмінності між групами досліджуваних із різним відчуттям психологічного простору за такими стратегіями психологічного подолання, як конфронтація, дистанціювання, самоконтроль, свобода, відповідальність і позитивна переоцінка та за наявністю конфлікту в особистісній сфері за суверенністю речей, звичок, території й цінностями, що й визначає подальші перспективи дослідження даної проблематики.

Висновки та перспективи подальших наукових досліджень. На основі аналізу сутності феномену свободи, нами визначено поняття свободи як можливість і здатність здійснювати рефлексію і саморефлексію, переживати почуття свободи чи несвободи, здійснювати вибір; активно і відповідально діяти. У результаті аналізу зарубіжних та вітчизняних концепцій поняття свободи було узагальнено типи свободи та запропоновано концептуальну модель свободи, які заклали основу нашого емпіричного дослідження. У результаті проведення емпіричного дослідження психологічної свободи особистості як компоненту суб'єктивної картини світу молоді, було виявлено, що психологічна свобода в юнацькому віці пов'язана з низкою психологічних властивостей особистості (самопізнанням, розвитком самосвідомості, особистісною автономією, психологічним благополуччям юнаків та дівчат, рівнем їх рефлексії та ін.). Студенти першого курсу вважають себе більш вільними та незалежними, ніж студенти старших курсів, що може бути зумовлено їх нижчою самокритичністю та недостатнім усвідомленням відповідальності, яка стоїть за свободою. Сутність внутрішньої свободи для студентів визначається через можливість вибору та як суб'єктивне переживання (відчуття та стану). Для досягнення вищого рівня внутрішньої свободи студенти потребують відповідно високого рівня зовнішньої свободи, зокрема для студентів старших курсів актуальною $€$ потреба у фінансовій незалежності. Питання внутрішньої свободи $є$ значущим для молоді, адже усвідомлення важливості внутрішньої свободи і бажання мати високий рівень свободи відзначається у всіх студентів. На основі теоретичного та емпіричного дослідження, можна стверджувати, що відчуття і усвідомлення свободи є необхідними умовами психологічного здоров'я особистості, тому перспективним убачаємо дослідження та розробку методів підвищення наявного рівня психологічної свободи та психологічного благополуччя особистості.

\section{СПИСОК ПОСИЛАНЬ}

Белова, А. (2008). Изучение свободы в отечественной психологии. (Вып. 18). Самара: НТЦ Леонтьев, Д. (2000). Психология свободы: к постановке проблемы самодетерминации личности. Психологический журнал, 21,15-25.

Корчікова, I. (2013). Адаптація і стандартизація опитувальника особистісної автономії для підлітків і юнаків. Науково-практичний та освітньо-методичний журнал, 9, 47-52.

Кузьмина, Е. (2008). Проблема свободи в психологии. Санкт-Петербург: Питер.

Випуск 13, 2019. Збірник наукових праць РДГУ 
Фромм, Э. (2016). Бегство от свободыл. Москва: АСТ, Neoclassic,

\title{
REFERENCES
}

Belova., A.(2008). Izucheniye svobody $v$ otechestvennoy psikhologii [The study of freedom in domestic psychology]. (Vyp. 18). Samara: NTTs. [in Russian].

Leontev, D. (2000). Psikhologiya svobody: k postanovke problemy samodeterminatsii lichnosti [Psychology of freedom: to the formulation of the problem of self-determination of personality]. Psikhologicheskiy zhurnal, 21, 15-25. [in Russian].

Korchikova, I. (2013). Adaptatsiya i standartizatsiya opituvalnika osobistisnoï avtonomiï dlya pidlitkiv i yunakiv [Adaptation and standardization of a grassroots specialist of special autonomy for financial and social security]. Naukovo-praktichyta osvitno-metodichnyzhumal, 9, 47-52. [in Ukrainian].

Kuzmina, E. (2008). Problema svobodi v psikhologii [The problem of freedom in psychology]. Sankt-Peterburg: Piter. [in Russian].

Fromm, E. (2016). Begstvo ot svobody [Escape from freedom].Moskva: AST. Neodassis. [in Russian].

\section{FEATURES OF UNDERSTANDING THE FREEDOM PHENOMENON IN ADOLESCENT AND YOUTH AGE}

\author{
Natalia Chmunevich \\ Graduate student \\ specialty "Psychology" \\ ORCID iD: 0000-0002-7699-1475
}

Vitalij Pavelkiv

Doctor of psychological sciences, professor, Dean of Faculty of Psychology and Natural Science Rivne State University of the Humanities ORCID iD:0000-0003-3321-9060 DOI https://doi.org/10.35619/prap_rv.vi13.142

Abstract. The article deals with the psychological aspect of the phenomenon of freedom. The theoretical analysis of the psychological approaches to the discovery of the essence of psychological phenomenon of freedom in foreign and native sources is done. It is proposed the theoretical model of psychological freedom of personality.

The concept of freedom changes significantly with age, depends on the level of development, thinking, personality, self-awareness, morality, as well as the integrity of the individual in the group, society, culture. It bears the imprint of ideas on freedom adopted at this level of development of society, determined by the orientation to freedom of age groups. In defining freedom in an integrated form, the social significance of this category is combined with individual understanding the result of personal experience of encountering obstacles, overcoming addictions.

Analyzing the idea of freedom, attitude to it and its achievement, we can say that it depends on many reasons, including age and individual characteristics, personality traits, the level of development of spiritual potential, consciousness and reflection, the system of education and training, norms, rights and laws adopted in society. Personality is the subject of life and the subject of its development, a person in non-classical psychology appears in a special sense - in the sense of the master and the bearer of freedom, the ability to self-determination, the ability to act as a cause and source of their actions. In this sense, freedom defines the ontology of human existence as a creature capable of self-determination, self-development, it characterizes its natural essence, which, however, is not manifested in every individual being. In general, the view of the inner freedom of the individual as a psychological phenomenon is presented, reflecting the semantic aspects of human relations with the world. Allows you to study it as an integral structure of personal experience and characteristic of the mental model of the world of personality. Within which some of its components act as markers of inner freedom.

Keywords: freedom, psychological freedom, will, phenomenon, subjectivity, selfdetermination, autonomy, self-awareness, self-efficacy. 